\title{
Comparative tests of a passenger car with compression ignition engine on chassis dynamometer during NEDC and WLTC tests and during RDE road test
}

Air pollution is a challenge for municipal authorities. Increased emission of PM10 and PM 2.5 particles is particularly noticeable in Poland primarily the autumn and winter period. That is due to the start of the heating season. According to the above data, road transport accounted for approximately 5\% of the creation of $P M_{10}$ particles, ca. $7 \%$ of $P M_{2.5}$ and approximately $32 \%$ for $N O_{x}$. In Poland, suspended particles $\left(P M_{10}\right.$ and $\left.P M_{2.5}\right)$ cause deaths of as many as 45,000 people a year. The issue of smog also affects other European cities. Therefore, it is necessary to undertake concrete efforts in order to reduce vehicle exhaust emissions as much as possible. It is therefore justifiable to reduce the emission of exhaust pollution, particularly $N O_{x}, P M, P N$ by conventional passenger cars powered by compression ignition engines. Emissions by these passenger cars have been reduced systematically. Comparative tests of the above emission of exhaust pollution were conducted on chassis dynamometer of such passenger car in NEDC cycle and in the new WLTC cycle in order to verify the level of emissions from this type of passenger car. Measurements of fuel consumption by that car were also taken. Emission of exhaust pollution and fuel consumption of the this car were also taken in the RDE road test.

Key words: emissions, pollutant emissions, particle matters, NEDC, WLTP, RDE

\section{Introduction}

Air pollution is a challenge for municipal authorities. Increased emission of $\mathrm{PM}_{10}$ and $\mathrm{PM}_{2.5}$ particles is particularly noticeable in Poland in the autumn and winter period. That is due to the start of the heating season.

According to KOBIZE (The National Centre for Emission Management) data [14], in 2016 the main sources of $\mathrm{PM}_{10}$, $\mathrm{PM}_{2.5}$, and PAH (Polycyclic Aromatic Hydrocarbons) emissions were non-industrial combustion processes $(45 \%, 48 \%$ and $88 \%$ respectively of the total amount of emissions of such substances, estimated at $259,156.3 \mathrm{Mg}, 145,506.9 \mathrm{Mg}$ and $146.3 \mathrm{Mg}$ ), the predominant share of which came from the combustion of solid fuels by households. In turn, in the case of nitric oxides $\left(\mathrm{NO}_{\mathrm{x}}\right)$, the industrial sector was the biggest source of emissions (38\% of the total amount of emissions of these substances, estimated at 726,431.2 Mg) and road transport $(32 \%)$. Lack of enough airflow causes the above dust and others to stay suspended above the city, as a result creating $\operatorname{smog}[1]$.

According to the above data, road transport accounted for approximately $5 \%$ of the creation of $\mathrm{PM}_{10}$ particles, ca. $7 \%$ of $\mathrm{PM}_{2.5}$ and approximately $32 \%$ for $\mathrm{NO}_{\mathrm{x}}$. In Poland, suspended particles $\left(\mathrm{PM}_{10}\right.$ and $\left.\mathrm{PM}_{2.5}\right)$ cause deaths of as many as 45,000 people a year. The issue of smog also affects other European cities. Therefore, it is necessary to undertake concrete efforts in order to reduce vehicle exhaust emissions as much as possible [2].

In the case of efforts in road transportation sector, several solutions are possible. One is to utilize vehicles with alternative propulsion systems (electric vehicles, vehicles equipped with fuel cells). The use of hybrid vehicles would be justifiable in the meantime. Nonetheless, in 2016 for example, alternative fuel vehicles and those with alternative propulsions accounted for a tiny minority $(0.03 \%)$ of the vehicles registered.
It is therefore justifiable to reduce the emission of exhaust pollution, particularly $\mathrm{NO}_{\mathrm{X}}, \mathrm{PM}, \mathrm{PN}$ by conventional passenger cars powered by compression ignition engines. Emissions by these passenger cars have been reduced systematically and are tested in laboratory tests (NEDC and WLTP (WLTC)) and also in RDE road cycles [3-9].

\section{Methodology}

\subsection{Test equipment}

For the purpose of studies on exhaust emissions in NEDC and WLTP tests the equipment of the Centre for Environmental Protection of the Motor Transport Institute was used. For the purpose of the tests there were used:

- gaseous emissions sampling and analysis system by AVL; during test was used configuration ,03 Diluted Bag Particle Diesel" consisting of:

- CFV-CVS exhaust gas sampling system type CVS i60 LD $\mathrm{S} 2$ by AVL,

- set of AMA i60 D1-CD LE analysers by AVL equipped with two-range analysers to measure the concentrations of the following gases:

- carbon dioxide $\mathrm{CO}_{2}$,

- nitrogen oxides $\mathrm{NO}_{\mathrm{X}}$,

- carbon monoxide $\mathrm{CO}$,

- total sum of hydrocarbons THC,

- methane $\mathrm{CH}_{4}$,

- particulate sampling system PSS i60 SD by AVL,

- particle counter AVL489 APC ADVANCED by AVL,

- microbalance MT5 by Mettler Toledo,

- M type thermo-hygro-barometer type LB-701, with a read-out LB-702B display by LABEL,

- Electronic scales PBD655-B120 by Mettler Toledo Company.

For RDE tests mobile analysers were used to measure hazardous RDEs - i.e. Engine Particle Sizer Model 3090 and mobile analyser of exhaust emissions SEMTECH DS 
(Fig. 1) of US Sensors Inc. [10]. An exhaust emission sample is taken by a mass exhaust emissions concentration probing device and delivered to the system through a heated path maintaining temperature of $191^{\circ} \mathrm{C}$. Exhaust are filtered to remove particle matter (in case of self-ignition engines) and the concentration of hydrocarbons is measured in the Flame Ionization Detector (FID). Next, the sample is cooled to $4^{\circ} \mathrm{C}$ and Non-dispersion Detector Ultra Violet analyser (NDUV) the concentrations of nitrogen oxide and nitrogen dioxide are measured, while the Non-dispersion Detector Infra-Red (NDIR) measures the concentration of $\mathrm{CO}$ and $\mathrm{CO}_{2}$. The measurement of oxygen is made through an electro-mechanical sensor. The device allows for recording the parameters read from the vehicle's diagnostic system and the geographical location via a GPS module (Table 1) $[11]$.

Table 1. Characteristics of SEMTECH DS mobile exhaust emissions analyser [11]

\begin{tabular}{|c|c|c|}
\hline Parameter & Test method & Accuracy \\
\hline $\begin{array}{l}\text { 1. Concentration of } \\
\text { CO }\end{array}$ & $\begin{array}{c}\text { NDIR - non-dispersive (infrared), } \\
\text { range } 0-10 \%\end{array}$ & $\pm 3 \%$ \\
\hline THC & $\begin{array}{l}\text { FID - flame ionisation, } \\
\text { range } 0-10,000 \mathrm{ppm}\end{array}$ & $\pm 2.5 \%$ \\
\hline $\mathrm{NO}_{\mathrm{x}}=\left(\mathrm{NO}+\mathrm{NO}_{2}\right)$ & $\begin{array}{c}\text { NDUV - non-dispersive (ultravio- } \\
\text { let), range } 0-3000 \mathrm{ppm}\end{array}$ & $\pm 3 \%$ \\
\hline $\mathrm{CO}_{2}$ & $\begin{array}{c}\text { NDIR - non-dispersive (infrared), } \\
\text { range } 0-20 \%\end{array}$ & $\pm 3 \%$ \\
\hline $\mathrm{O}_{2}$ & Electrochemical, range $0-20 \%$ & $\pm 1 \%$ \\
\hline $\begin{array}{l}\text { 2. Exhaust emis- } \\
\text { sions flow }\end{array}$ & $\begin{array}{l}\text { Mass flow intensity } \\
\mathrm{T}_{\max } \text { do } 700^{\circ} \mathrm{C}\end{array}$ & $\begin{array}{c} \pm 2.5 \% \\
\pm 1 \% \\
\end{array}$ \\
\hline 3. Heating time & $15 \mathrm{~min}$ & - \\
\hline 4. Response time & $\mathrm{T}_{90}<1 \mathrm{~s}$ & - \\
\hline $\begin{array}{c}\text { 5. Diagnostic } \\
\text { systems operated }\end{array}$ & $\begin{array}{l}\text { SAE J1850/SAE J1979 (LDV) } \\
\text { SAE J1708/SAE J1587 (HDV) } \\
\text { CAN SAE J1939/J2284 (HDV) }\end{array}$ & - \\
\hline
\end{tabular}

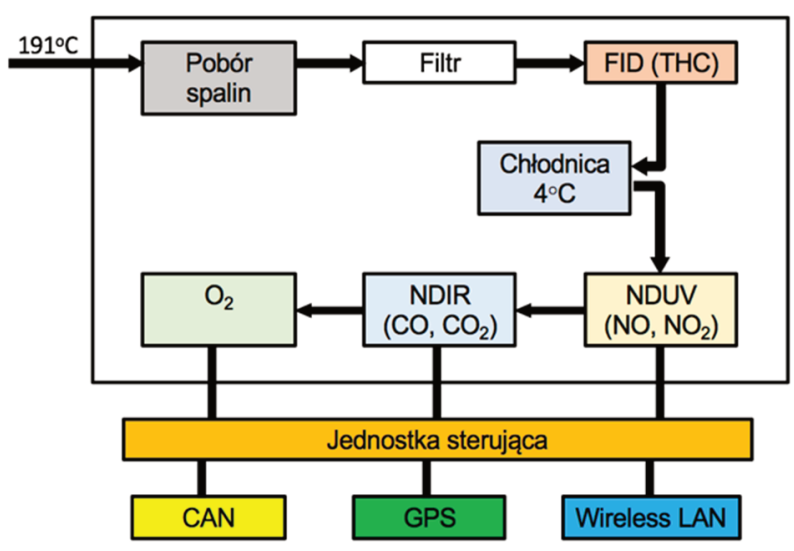

Fig. 1. Operating chart of SEMTECH DS analyser [11]

\subsection{Test cycles - NEDC, WLTP}

NEDC - The UDC+EUDC test cycle was used to test emissions and fuel consumption of light duty vehicles under EU type-approval [3]. The test is carried out on a chassis dynamometer. The entire cycle includes four ECE segments repeated non-stop, followed by one EUDC segment. Before the test, the vehicle must remain for at least 6 hours at a test temperature of $20-30^{\circ} \mathrm{C}$. Since 2000 , the idle period has been eliminated, i.e. the engine starts in $0 \mathrm{~s}$ and sampling begins at the same time. This modified cold start procedure is referred to as the New European Driving Cycle (NEDC) [3].

The Extra Urban Driving Cycle (EUDC) segment was added after the fourth ECE cycle to account for more aggressive high-speed driving modes. The maximum EUDC cycle speed is $120 \mathrm{~km} / \mathrm{h}$. An alternative EUDC cycle was also determined for vehicles with low energy consumption, with a maximum speed limited to $90 \mathrm{~km} / \mathrm{h}$ [3].

Emissions are collected during the cycle in accordance with the Constant Volume Sampling technique (CVS), analysed and expressed in $\mathrm{g} / \mathrm{km}$ for each pollutant. Table 2 summarizes selected parameters for ECE 15, EUDC and NEDC cycles [3].

Table 2. Characteristics of UDC, EUDC and NEDC test [3]

\begin{tabular}{|l|c|c|c|c|}
\hline Characteristics & Unit & UDC & EUDC & NEDC $^{\mathrm{b}}$ \\
\hline Distance & $\mathrm{km}$ & 0.9941 & 6.9549 & 10.9314 \\
\hline Total time & $\mathrm{s}$ & 195 & 400 & 1180 \\
\hline Idle time & $\mathrm{s}$ & 57 & 39 & 267 \\
\hline $\begin{array}{l}\text { Average speed } \\
\text { (incl. stops) }\end{array}$ & $\mathrm{km} / \mathrm{h}$ & 18.35 & 62.59 & 33.35 \\
\hline $\begin{array}{l}\text { Average driving } \\
\text { speed (excl. stops) }\end{array}$ & $\mathrm{km} / \mathrm{h}$ & 25.93 & 69.36 & 43.10 \\
\hline Maximum speed & $\mathrm{km} / \mathrm{h}$ & 50 & 120 & 120 \\
\hline $\begin{array}{l}\text { Average } \\
\text { acceleration }\end{array}$ & $\mathrm{m} / \mathrm{s}^{2}$ & 0.599 & 0.354 & 0.506 \\
\hline $\begin{array}{l}\text { Maximum } \\
\text { acceleration }\end{array}$ & $\mathrm{m} / \mathrm{s}^{2}$ & 1.042 & 0.833 & 1.042 \\
\hline $\begin{array}{l}\text { a Calculated using central difference method } \\
\text { b Four repetitions of UDC followed by one EUDC }\end{array}$ & \multicolumn{5}{|l|}{} \\
\hline
\end{tabular}

WLTC - Under conditions defined by EU law, the Worldwide Harmonised Light Vehicle Test Cycle (WLTC) laboratory test is used to measure fuel consumption and $\mathrm{CO}_{2}$ emissions from passenger cars, as well as their pollutant emissions [4-5].

WLTC replaces the European procedure based on NEDC for light vehicle type approval tests, with the transition from NEDC to WLTC in 2017-2019 [3-5].

WLTP procedures include several WLTC test cycles applicable to the vehicle category with different power to mass ratio (PMR), Table 3. The PMR parameter is defined as the ratio of rated power $(\mathrm{W}) /$ curb mass $(\mathrm{kg})$. Curb mass (or curb weight) means "unloaded mass" as defined in ECE R83. The cycle definitions may also depend on the maximum speed (v_max), which is the maximum vehicle speed declared by the manufacturer (ECE R68) and not the use limitation or safety-related restriction. Cyclical modifications can include steering problems for vehicles with power to mass indicators near boundary lines or at maximum speeds limited to values below the maximum speed required by cycle [4-5].

With the highest power-to-mass ratio, Class 3 is representative of vehicles driven in Europe and Japan. Class 3 vehicles are divided into 2 subclasses according to their maximum speed: Class 3a with v_max $<120 \mathrm{~km} / \mathrm{h}$ and 
Class $3 b$ with v_max $\geq 120 \mathrm{~km} / \mathrm{h}$. Selected parameters of the Class 3 cycles are shown in Table 4, and the vehicle speed for Class $3 b$ is shown in Fig. 2 [4-5].

Table 3. Characteristics of ECE15, EUDC and NEDC test [4-5]

\begin{tabular}{|c|c|c|c|}
\hline Category & $\begin{array}{l}\mathrm{PMR} \\
{[\mathrm{W} / \mathrm{kg}]}\end{array}$ & $\begin{array}{l}\text { v_max } \\
{[\mathrm{km} / \mathrm{h}]}\end{array}$ & Speed Phase Sequence \\
\hline Class $3 \mathrm{~b}$ & \multirow[t]{2}{*}{ PMR $>34$} & $\begin{array}{c}\text { v_max } \\
120\end{array}$ & $\begin{array}{l}\text { Low 3 + Medium 3-2 + } \\
\text { High 3-2 + Extra High } 3\end{array}$ \\
\hline Class 3a & & $\begin{array}{l}\text { v_max } \\
120\end{array}$ & $\begin{array}{l}\text { Low 3 + Medium 3-1 + } \\
\text { High 3-1 + Extra High 3 }\end{array}$ \\
\hline Class 2 & $\begin{aligned} 34 & \geq \text { PMR } \\
& >22\end{aligned}$ & - & $\begin{array}{c}\text { Low } 2+\text { Medium } 2+\text { High } 2 \\
+ \text { Extra High } 2\end{array}$ \\
\hline Class 1 & $\mathrm{PMR} \leq 22$ & - & Low $1+$ Medium $1+$ Low 1 \\
\hline
\end{tabular}

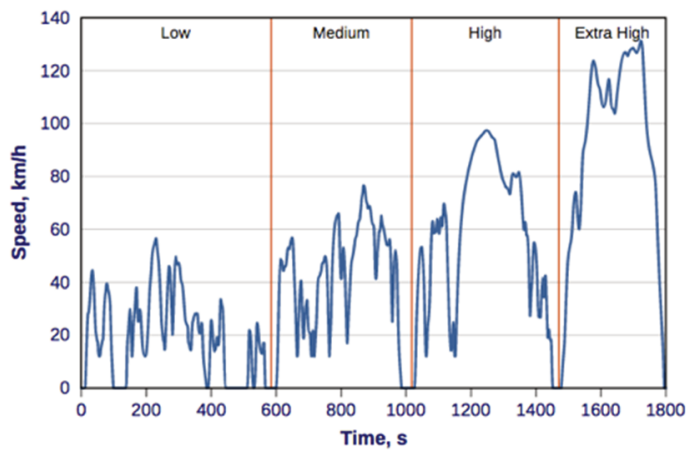

Fig. 2. WLTC cycle for Class $3 \mathrm{~b}$ vehicles [4-5]

Table 4. WLTC Class 3 cycle: selected parameters [4-5]

\begin{tabular}{|c|c|c|c|c|c|c|c|c|c|}
\hline \multirow[t]{2}{*}{$\begin{array}{l}0 \\
\frac{\mathscr{Z}}{2} \\
\frac{\pi}{2}\end{array}$} & 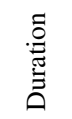 & 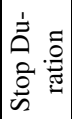 & 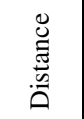 & 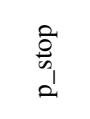 & $\begin{array}{l}\underset{\varpi}{\leftrightarrows} \\
\rangle_{1} \\
>\end{array}$ & 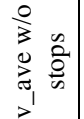 & 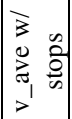 & $\underset{\sigma}{\Xi_{J}}$ & $\begin{array}{l}\underset{\Xi}{夭} \\
\underbrace{}_{1} \\
\sigma^{\prime}\end{array}$ \\
\hline & $\mathrm{s}$ & $\mathrm{s}$ & $\mathrm{m}$ & & $\mathrm{km} / \mathrm{h}$ & $\mathrm{km} / \mathrm{h}$ & $\mathrm{km} / \mathrm{h}$ & $\mathrm{m} / \mathrm{s}^{2}$ & $\mathrm{~m} / \mathrm{s}^{2}$ \\
\hline \multicolumn{10}{|c|}{ Class 3b (v_max $\geq 120 \mathrm{~km} / \mathrm{h})$} \\
\hline Low 3 & 589 & 156 & 3095 & $26.5 \%$ & 56.5 & 25.7 & 18.9 & -1.47 & 1.47 \\
\hline $\begin{array}{c}\text { Medium } \\
3-2\end{array}$ & 433 & 48 & 4756 & $11.1 \%$ & 76.6 & 44.5 & 39.5 & -1.49 & 1.57 \\
\hline High 3-2 & 455 & 31 & 7162 & $6.8 \%$ & 97.4 & 60.8 & 56.7 & -1.49 & 1.58 \\
\hline $\begin{array}{l}\text { Extra- } \\
\text { High } 3\end{array}$ & 323 & 7 & 8254 & $2.2 \%$ & 131.3 & 94.0 & 92.0 & -1.21 & 1.03 \\
\hline Total & 1800 & 242 & 23266 & & & & & & \\
\hline \multicolumn{10}{|c|}{ Class 3a (v_max $<120 \mathrm{~km} / \mathrm{h})$} \\
\hline Low 3 & 589 & 156 & 3095 & $26.5 \%$ & 56.5 & 25.7 & 18.9 & -1.47 & 1.47 \\
\hline $\begin{array}{c}\text { Medium } \\
3-1\end{array}$ & 433 & 48 & 4721 & $11.1 \%$ & 76.6 & 44.1 & 39.3 & -1.47 & 1.28 \\
\hline High 3-1 & 455 & 31 & 7124 & $6.8 \%$ & 97.4 & 60.5 & 56.4 & -1.49 & 1.58 \\
\hline $\begin{array}{l}\text { Extra- } \\
\text { High } 3 \\
\end{array}$ & 323 & 7 & 8254 & $2.2 \%$ & 131.3 & 94.0 & 92.0 & -1.21 & 1.03 \\
\hline Total & 1800 & 242 & 23194 & & & & & & \\
\hline
\end{tabular}

The homologation tests carried out in laboratory conditions in the chassis dynamometer are aimed at determining the average exhaust gas emission and fuel consumption in newly produced vehicles. So far, the NEDC cycle has been considered too "easy" to reflect real road conditions. For this reason, works have begun on a new WLTC testing procedure.
Figure 3 shows the most important differences between WLTC and NEDC tests.

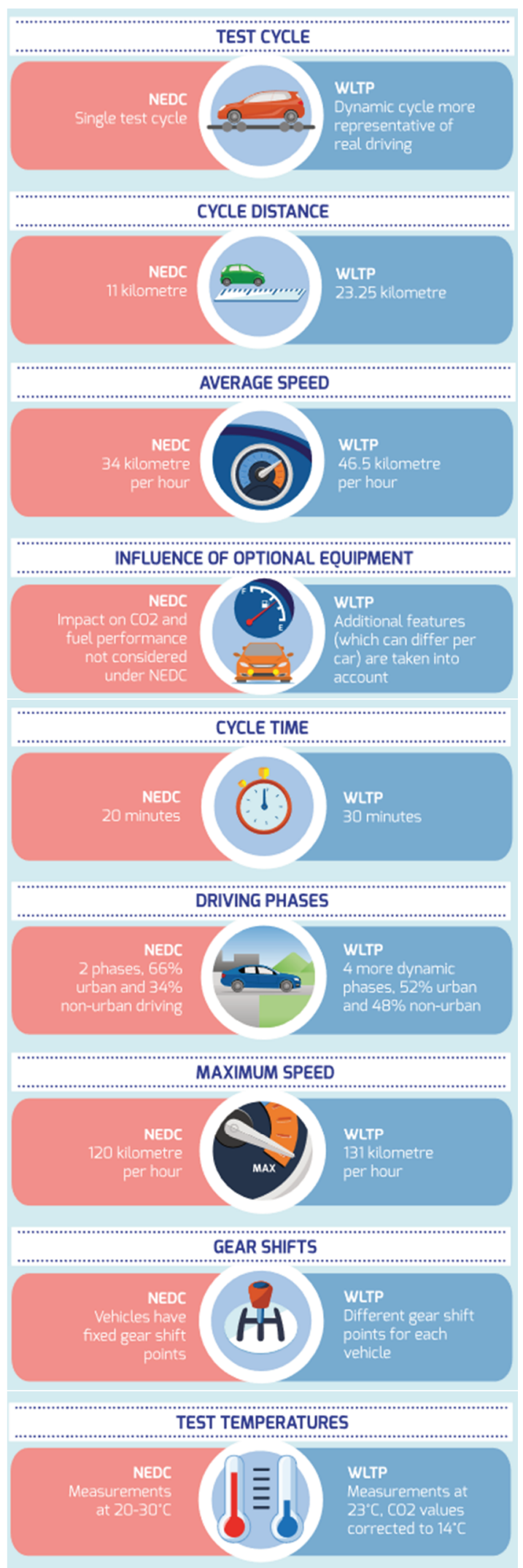

Fig. 3. Differences between NEDC and WLTC [12] 
Comparing WLTC with NEDC, you can see that many changes have been made. First, the effect of additional equipment and different engine configuration versions was taken into account, as well as the type of gearbox used in the vehicle (the gearbox change in the case of the manual gearbox is calculated). But it is not everything. The distance and duration of the cycle have been extended. Now, it is extended by 10 minutes (WLTC -30 minutes, NEDC -20 minutes) and longer by $12 \mathrm{~km}$ (WLTC - $23 \mathrm{~km}$, NEDC $11 \mathrm{~km}$ ). The downtime has been shortened. Accurate tests have shown that in real traffic conditions, the vehicle's idle time is shorter than previously assumed. For this reason, it was reduced from $25 \%$ in NEDC to $13 \%$ in the WLTC cycle [3-5]. An important change is the introduction of differences in the cycle depending on the vehicle's power and the mass ratio in the tested vehicle. Three categories were distinguished. It should be noted, however, that in a larger number of cases, the third category applies to vehicles sold in Europe - above $34 \mathrm{~kW} /$ ton [12].

\subsection{RDE cycle - real driving emissions}

The presented tests are supplemented with real driving emissions (RDE) tests. To perform those tests first the test route had to be specified that would be representative for the tests and fulfil the requirements [6-9]. The requirements set forth by the legislator are presented in the Table 5 .

Table 5. Requirements regarding the RDE test route [6-9]

\begin{tabular}{|c|c|}
\hline Parameter & Requirements \\
\hline \multirow{3}{*}{$\begin{array}{l}\text { Ambient tempera- } \\
\text { ture }\left(\mathrm{T}_{\mathrm{z}}\right)\end{array}$} & normal range: $0{ }^{\circ} \mathrm{C} \leq \mathrm{T}_{\mathrm{z}}<30^{\circ} \mathrm{C}$ \\
\hline & lower extended range: $-7^{\circ} \mathrm{C} \leq \mathrm{T}_{\mathrm{z}}<0{ }^{\circ} \mathrm{C}$ \\
\hline & upper extended range: $30^{\circ} \mathrm{C}<\mathrm{T}_{\mathrm{z}} \leq 35^{\circ} \mathrm{C}$ \\
\hline \multirow{2}{*}{$\begin{array}{l}\text { Topographic } \\
\text { height }(\mathrm{h})\end{array}$} & normal range: $\mathrm{h} \leq 700 \mathrm{~m}$ a.s.l \\
\hline & extended range: $700<\mathrm{h} \leq 1300 \mathrm{~m}$ a.s.l \\
\hline \multirow{3}{*}{$\begin{array}{l}\text { Impact of external } \\
\text { weather and road } \\
\text { parameters and the } \\
\text { driving style }\end{array}$} & accumulated height: less than $1200 \mathrm{~m} / 100 \mathrm{~km}$ \\
\hline & $\begin{array}{l}\text { (RPA): greater than } \mathrm{RPA}_{\min } \text { (in all driving condi- } \\
\text { tions) }\end{array}$ \\
\hline & $\begin{array}{l}\text { product of acceleration and speed }\left(\mathrm{v} \cdot \mathrm{a}_{\mathrm{pos}}\right) \text { : } \\
\text { less than } \mathrm{v} \cdot \mathrm{a}_{\text {pos } \min } \text { (in all driving conditions) }\end{array}$ \\
\hline \multirow{2}{*}{$\begin{array}{l}\text { Thermal condition } \\
\text { of the vehicle prior } \\
\text { to tests }\end{array}$} & $\begin{array}{l}\text { cold start: coolant less than } 70{ }^{\circ} \mathrm{C} \text {, } \\
\text { time of at least } 300 \mathrm{~s},\end{array}$ \\
\hline & emission upon cold start not included in RDE test \\
\hline Single vehicle stop & no more than $180 \mathrm{~s}$ \\
\hline $\begin{array}{l}\text { Exhaust after- } \\
\text { treatment system's } \\
\text { operation }\end{array}$ & $\begin{array}{l}\text { single regeneration of PM filter can result in RDE } \\
\text { test repetition; two regenerations are included in } \\
\text { the results of exhaust emissions in RDE test }\end{array}$ \\
\hline $\begin{array}{l}\text { Driving comfort } \\
\text { system operation }\end{array}$ & $\begin{array}{l}\text { used normally according to purpose (e.g. air- } \\
\text { conditioning system) }\end{array}$ \\
\hline Vehicle load & $\begin{array}{l}\text { mass of vehicle: driver (and passenger) and test } \\
\text { equipment; max. load }<90 \% \text { of the sum of } \\
\text { weight of passengers and vehicle's usable mass }\end{array}$ \\
\hline Test requirement & duration $90-120 \mathrm{~min}$ \\
\hline \multirow{5}{*}{$\begin{array}{l}\text { Requirements for } \\
\text { the urban test part }\end{array}$} & $29-44 \%$ of the entire test length \\
\hline & distance more than $16 \mathrm{~km}$ \\
\hline & speed $(\mathrm{v}): \mathrm{v} \leq 60 \mathrm{~km} / \mathrm{h}$ \\
\hline & average speed: $15-40 \mathrm{~km} / \mathrm{h}$ \\
\hline & break: $6-30 \%$ of the total urban time \\
\hline \multirow{3}{*}{$\begin{array}{l}\text { Requirements for } \\
\text { the rural part }\end{array}$} & $23-43 \%$ of the entire test length \\
\hline & distance: greater than $16 \mathrm{~km}$ \\
\hline & vehicle's speed(v): $60 \mathrm{~km} / \mathrm{h}<\mathrm{v} \leq 90 \mathrm{~km} / \mathrm{h}$ \\
\hline \multirow{5}{*}{$\begin{array}{l}\text { Requirements for } \\
\text { the motorway part }\end{array}$} & $23-43 \%$ of the entire test length \\
\hline & distance: greater than $16 \mathrm{~km}$ \\
\hline & vehicle's speed(v): v > $90 \mathrm{~km} / \mathrm{h}$ \\
\hline & $\begin{array}{l}\text { driving speed of more than } 100 \mathrm{~km} / \mathrm{h} \text { for at least } \\
5 \mathrm{~min}\end{array}$ \\
\hline & $\begin{array}{l}\text { driving speed of more than } 145 \mathrm{~km} / \mathrm{h} \text { for at least } \\
3 \% \text { of the time }\end{array}$ \\
\hline
\end{tabular}

The works on outlining the test route were performed by the Motor Transport Institute. To have the test route specified was a priority because of the further possibility of conducting the tests (Fig. 4).

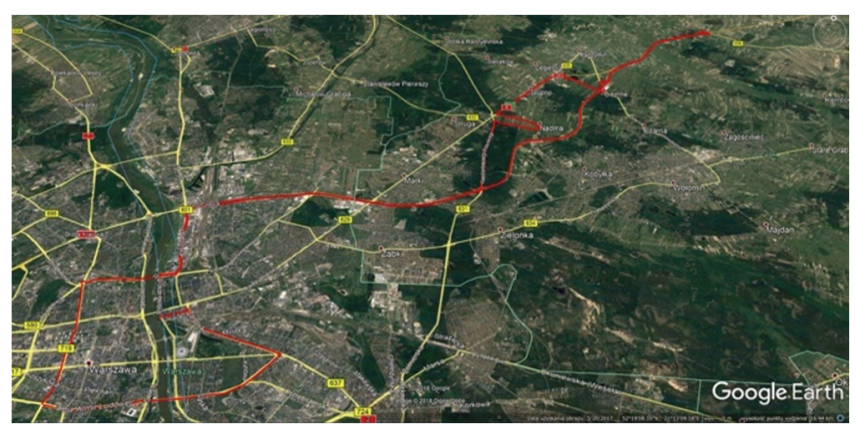

Fig. 4. RDE test route

\section{The object of tests}

The tests were performed with the use of M1 category vehicle with a self-ignition engine complying with Euro 6 emission level. Key technical parameters of the vehicle are presented in the Table 6 below and the vehicle is shown in Fig. 5.

Table 6. Chosen technical parameters of the vehicle used in the tests

\begin{tabular}{|l|c|c|}
\hline \multicolumn{1}{|c|}{ Parameter } & Unit & Value \\
\hline Length & $\mathrm{mm}$ & 4855 \\
\hline Width & $\mathrm{mm}$ & 1860 \\
\hline Height & $\mathrm{mm}$ & 1465 \\
\hline Wheelbase & $\mathrm{mm}$ & 2805 \\
\hline Engine & - & $\begin{array}{c}\text { Combustion, piston, } \\
\text { R4 16V, self-ignition }\end{array}$ \\
\hline Engine displacement & $\mathrm{cm}^{3}$ & 1598 \\
\hline Power & $\mathrm{kW} / \mathrm{rpm}$ & $136 / 4000$ \\
\hline Max. rotational speed & $\mathrm{Nm} / \mathrm{rpm}$ & $320 / 2000-2250$ \\
\hline Compression ratio & - & 15.7 \\
\hline
\end{tabular}
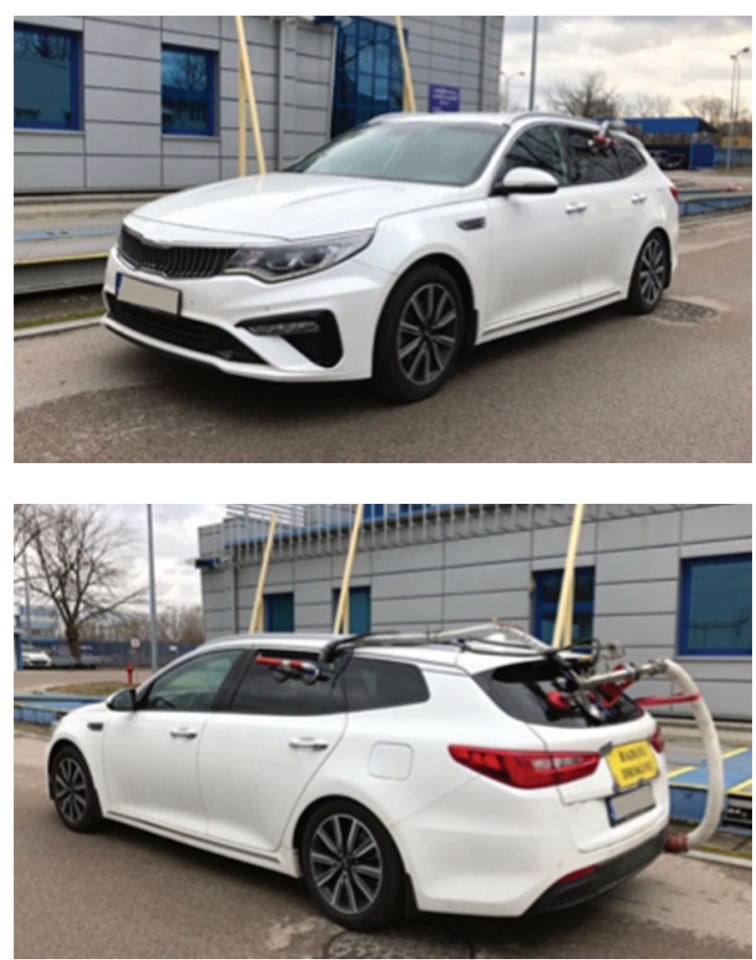

Fig. 5. Vehicle used for tests - overview 


\section{Test results}

\subsection{NEDC and WLTP cycles}

Multiple tests performed on the chassis dynamometer allowed for determining not only the average exhaust emissions but also the concentration of pollutants of exhaust emissions and the number of particle matters.

Figures below (Figs 6-7) present for example results of the number of PM in respective phases for NEDC and WLTC cycles. It can be noticed that the result in NEDC is smaller than in WLTC. The differences are also noticeable in respective phases. In the urban part (UDC - NEDC and Low - WLTC) those differences are considerable. Then in NEDC a much lower emission of particle matters was observed in EUDC - rural part as compared to the rural part in Extra High of WLTC cycle.

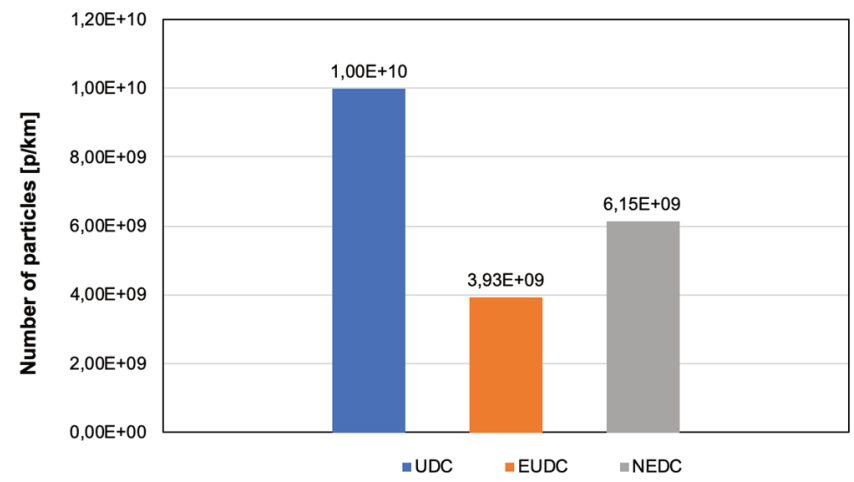

Fig. 6. Particle matters in NEDC and its phases

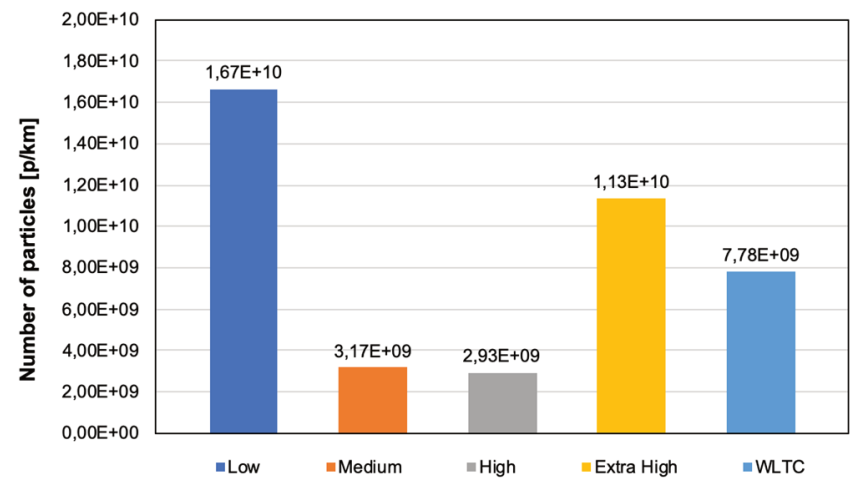

Fig. 7. Particle numbers in WLTP and its phases

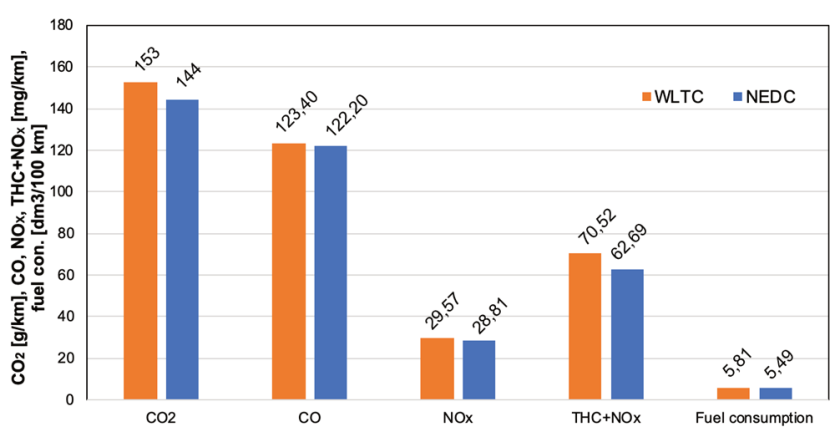

Fig. 8. Comparison of emissions in the tested vehicle in NEDC and WLTC cycles
During the tests of the tested vehicle attention was given to differences in emission of $\mathrm{CO}, \mathrm{NO}_{\mathrm{x}}$ and $\mathrm{THC}$. It has been observed that in WLTC the tested vehicle characterised with a higher emission of those gases.

As regards carbon oxide the difference was equal to approx. $1 \%$ to the disadvantage of NEDC (Fig. 8). As regards nitrogen oxides $\left(\mathrm{NO}_{\mathrm{x}}\right)$ the difference was $2.6 \%$ and was greater in WLTC. As regards hydrocarbons those differences are even greater.

\subsection{RDE cycle}

The tests performed on the chassis dynamometer were supplemented with RDE tests along a test route outlined in accordance with the requirements. The vehicle was tested in terms of hazardous exhaust emissions. The analyses were made based on window averaging method. The tests focused on the average emissions of $\mathrm{CO}_{2}, \mathrm{CO}, \mathrm{HC}, \mathrm{NO}_{\mathrm{x}}, \mathrm{PN}$ and fuel consumption. The analyses allowed for determining the emissions of respective gases in a breakdown into cycle phases and for determining the average emission. As regards $\mathrm{CO}_{2}-$ its emission in $\mathrm{RDE}$ cycle was equal to 187.6 $\mathrm{g} / \mathrm{km}$.

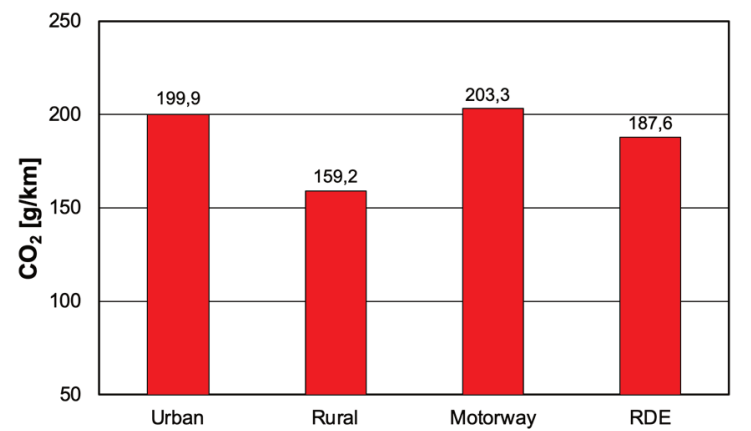

Fig. 9. Emissions of $\mathrm{CO}_{2}$ in respective phases of RDE cycle and average $\mathrm{CO}_{2}$ emission in this cycle

The fuel consumption of the tested vehicle remained at a relatively even level (Fig. 10). Only in the rural part the tested vehicle characterised with considerably lower fuel consumption. The average fuel consumption according to the test was equal to $7.05 \mathrm{dm}^{3}$ per $100 \mathrm{~km}$.

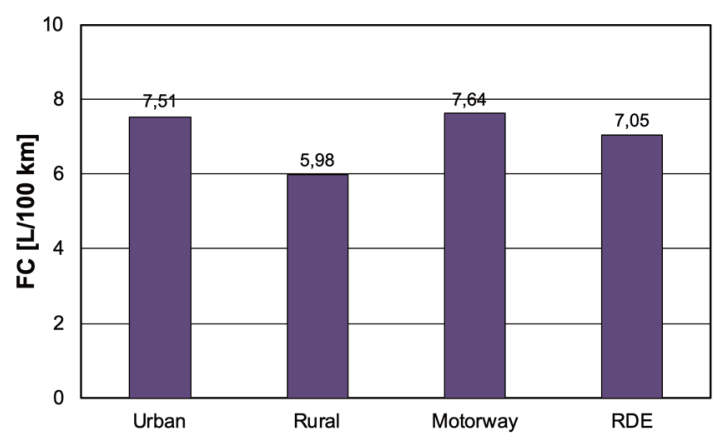

Fig. 10. Fuel consumption in respective RDE cycle phases and average fuel consumption in this cycle

During the RDE cycles of the tested vehicle measured were emissions in respective phases and average emission of $\mathrm{CO}$ and hydrocarbons. In the first case the emission levels were almost constant for all cycle phases. Therefore, 
also the average value did not differ from those in respective phases. For the purpose of analysing data, a Conformity Factor $(\mathrm{CF})$ was determined for every substance. Based on that it was possible to determine whether this Factor falls within the limit. As regards the tested vehicle this was achieved in case of $\mathrm{CO}$ (Fig. 11).

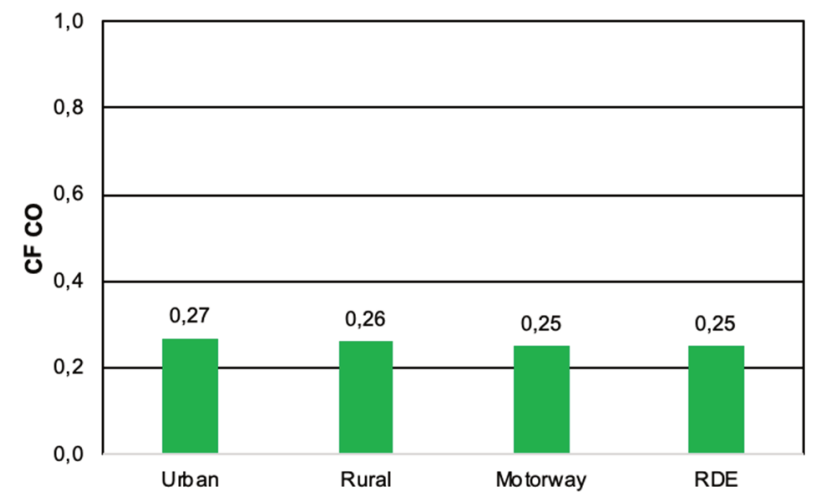

Fig. 11. CF for $\mathrm{CO}$ emissions in respective phases of RDE cycle and average $\mathrm{CO}$ emission in this cycle

A similar situation related to emission of hydrocarbons. The highest emission of hydrocarbons was recorded in the motorway phase. However, the differences between the phases are minor. This can be seen in Fig. 12 presenting $C F$ for hydrocarbons.

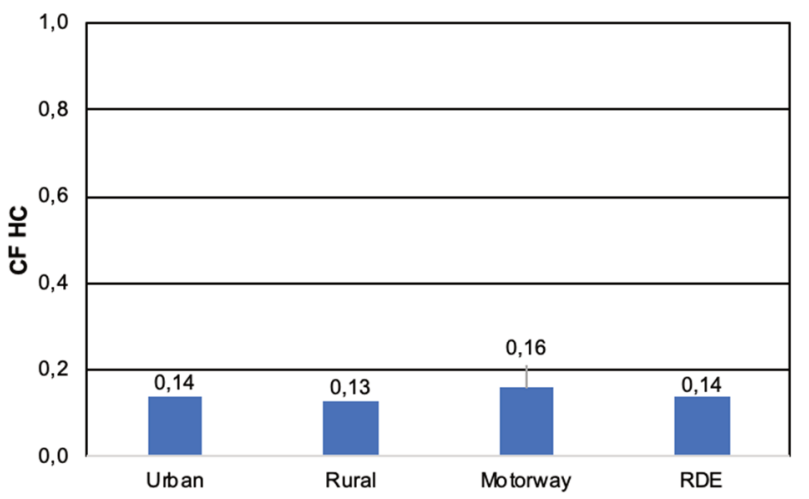

Fig. 12. CF for hydrocarbons in respective phases of RDE cycle and average emission of hydrocarbons in this cycle

The emissions of nitrogen oxides in the tested vehicle fell within the limit $\mathrm{CF}=1.5$. The result was even significantly lower. The tested vehicle with a self-ignition engine meeting the Euro 6 emission level standard, also fulfilled the requirements of RDE cycle. Moreover, the lowest emission of nitrogen oxides was recorded in the motorway part of RDE cycle (Fig. 13) and the highest - in the rural part. $\mathrm{CF}$ for the entire test was 0.39 .

Also, it should be noted that the requirements in terms of PN emissions were fulfilled (Fig. 14). Therefore, it can be concluded that modern self-ignition engines do not have problems in fulfilling the exhaust emission standards in relation to $\mathrm{PN}$ emissions.

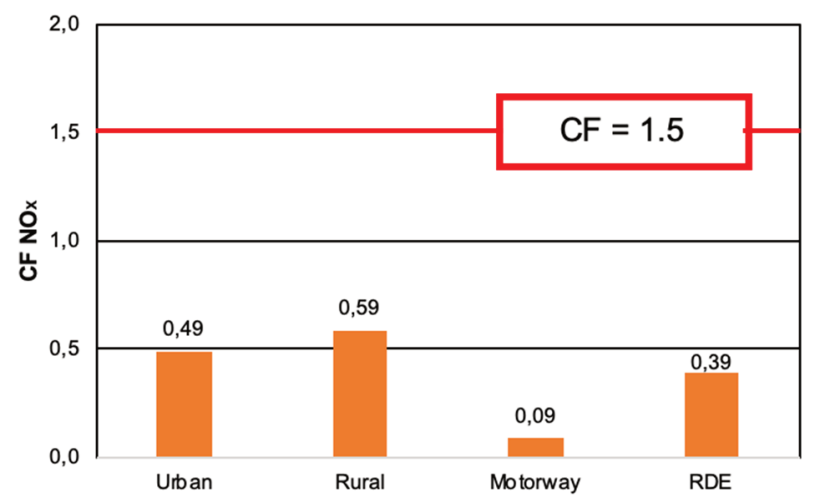

Fig. 13. CF for nitrogen oxides in respective phases of RDE cycle and average emissions of nitrogen oxides in this cycle

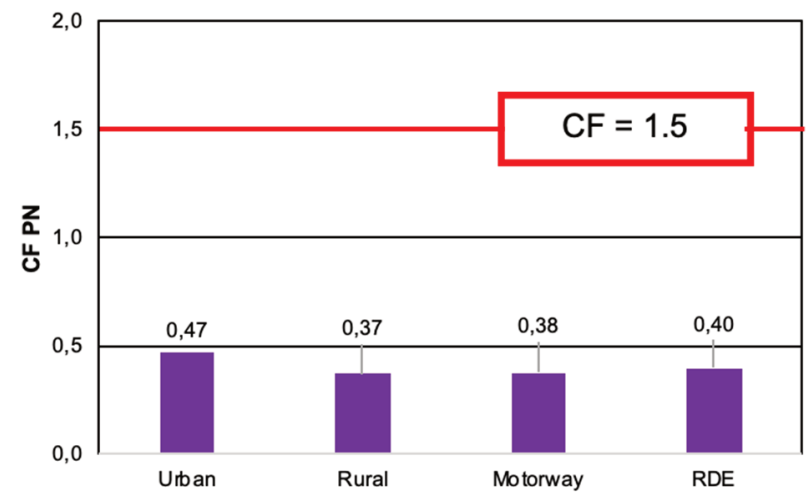

Fig. 14. PN emissions in respective phases of RDE cycle and average PN emissions

On Fig. 15 are given a comparison between the results of road emissions and fuel consumption of the tested vehicle in respective driving cycles.

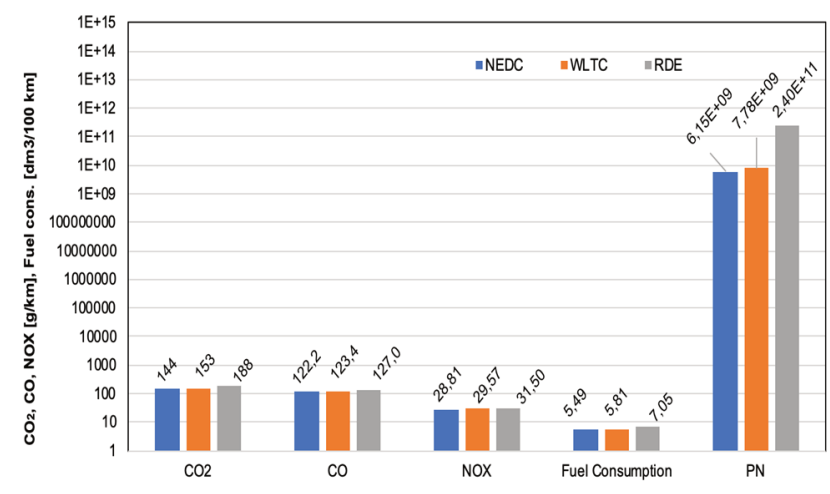

Fig. 15. Comparison of chosen results of road emissions and fuel consumption in the tested vehicle in respective driving cycles.

\section{Conclusions}

The results of the exhaust emissions in comparative cycles (NEDC, WLTC and RDE cycles) prove that those obtained in RDE cycle - in the case of the tested vehicle with a self-ignition engine - are relatively more unfavourable, though often similar to the results in other test cycles. The tested passenger car fulfils the requirements concerning $\mathrm{RDE}$ tests on the tested route for such cycle, and the test route is consistent with the requirements regarding such 
routes. Also, the requirements regarding the dynamic of the vehicle's trip along the route have been met. The application of the RDE cycle to verify the results of exhaust emis- sions tests on a chassis dynamometer is therefore fully justified.

\section{Nomenclature}

CAN Controller Area Network

CF Conformity Factor

GPS Global Positioning System

NEDC New European Driving Cycle
RDE Real Driving Emissions

WLAN Wireless Local Area Network

WLTP Worldwide harmonised Light duty Vehicle Test Procedure

\section{Bibliography}

[1] Krajowy bilans emisji $\mathrm{SO}_{2}, \mathrm{NO}_{\mathrm{x}}, \mathrm{CO}, \mathrm{NH}_{3}, \mathrm{NMLZO}$, pyłów, metali ciężkich i TZO za lata2015-2016 w układzie klasyfikacji SNAP. KOBiZE, styczeń 2018.

[2] NIK. Ochrona powietrza przed zanieczyszczeniami, 2018.

[3] United Nations. Agreement concerning the Adoption of Uniform Technical Prescriptions for Wheeled Vehicles, Equipment and Parts which can be Fitted and/or be Used on Wheeled Vehicles and the Conditions for Reciprocal Recognition of Approvals Granted on the Basis of these Prescriptions. Addendum 82 I Regulation No. 83 Revision 5 Uniform provisions concerning the approval of vehicles with regard to engine fuel requirements. E/ECE/324/Rev.1/Add/82/Rev.5-

E/ECE/TRANS/505/Rev.1/Add.82/Rev.5, 4.02.2015.

[4] Global Registry Addendum15: Global technical regulation No. 15. Worldwide harmonized Light Vehicles Test Procedure. ECE/TRANS/180/Add.15.

[5] Proposal for Amendment 4 to UN GTP No 15 (Wordwide harmonized Light vehicles Test Procedures (WLTP). ECE/TRANS/WP.29/2018/71.

[6] Commission Regulation (EU) 2016/427 of 10 March 2016 amending Regulation (EC) No 692/2008 as regards emissions from light passenger and commercial vehicles (Euro 6).

[7] Commission Regulation (EU) 2016/646 of 20 April 2016 amending Regulation (EC) No 692/2008 as regards emissions from light passenger and commercial vehicles (Euro 6).

[8] Commission Regulation (EU) 2017/1154 of 7 June 2017 amending Regulation (EU) 2017/1151 supplementing Regulation (EC) No 715/2007 of the European Parliament and of the Council on type-approval of motor vehicles with respect to emissions from light passenger and commercial vehicles
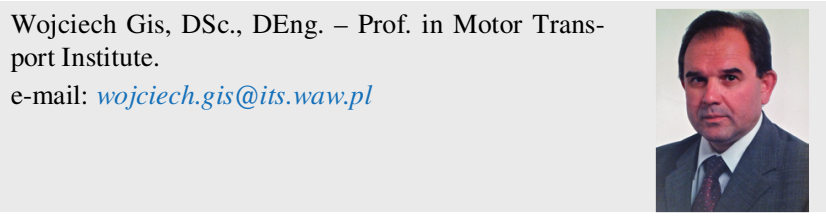

Piotr Wiśniowski, DEng. - Environment Protection Centre in Motor Transport Institute. e-mail: piotr.wisniowski@its.waw.pl
(Euro 5 and Euro 6) and on access to vehicle repair and maintenance information, amending Directive 2007/46/EC of the European Parliament and of the Council, Commission Regulation (EC) No 692/2008 and Commission Regulation (EU) No 1230/2012 and repealing Regulation (EC) No 692/2008 and Directive 2007/46/EC of the European Parliament and of the Council as regards real-driving emissions from light passenger and commercial vehicles (Euro 6).

[9] Commission Regulation (EU) 2018/1832 of 5 November 2018 amending Directive 2007/46/EC of the European Parliament and of the Council, Commission Regulation (EC) No 692/2008 and Commission Regulation (EU) 2017/1151 for the purpose of improving the emission type approval tests and procedures for light passenger and commercial vehicles, including those for in-service conformity and realdriving emissions and introducing devices for monitoring the consumption of fuel and electric energy.

[10] Semtech DS: On Board Vehicle Emissions Analyzer. User Manual.

[11] JAKUBIAK-LASOCKA, J., LASOCKI, J., BADYDA, A.J. The influence of particulate matter on respiratory morbidity and mortality in children and infants. Advances in Experimental Medicine and Biology. 2015, 849, 39-48.

[12] www.wltpfacts.eu

[13] Commission Implementing Regulation (EU) 2018/1002 of 16 July 2018 amending Implementing Regulation (EU) $2017 / 1153$ to clarify and simplify the correlation procedure and to adapt it to changes to Regulation (EU) 2017/1151.

[14] Wdrożenie procedury dotyczącej przejazdu dla realizacji badań emisji zanieczyszczeń spalin (RDE). Praca statutowa 06/18/ITS/008. Instytut Transportu Samochodowego.

Maciej Gis, DEng. - Environment Protection Centre in Motor Transport Institute.

e-mail: maciej.gis@its.waw.pl

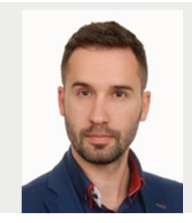

Mateusz Bednarski, MEng. - Faculty of Automotive and Construction Machinery Engineering, Warsaw University of Technology.

e-mail: mateusz.bednarski@pw.edu.pl 